\title{
Evaluación del daño en el DNA espermático
}

\author{
Cortés-Gutiérrez EI*, Dávila-Rodríguez MI*, López-Fernández C**, Fernández JL***, Gosálvez J** \\ *Departamento de Genética. Centro de Investigación Biomédica del Noreste. Instituto Mexicano del Seguro \\ Social (IMSS), Monterrey, Nuevo León. México. **Departamento de Biología. Unidad de Genética. Universidad \\ Autónoma de Madrid (UAM). Madrid. ***Unidad de Investigación. Hospital Juan Canalejo. La Coruña.
}

Actas Urol Esp. 2007;31(2):120-131

\section{RESUMEN}

\section{EVALUACIÓN DEL DAÑO EN EL DNA ESPERMÁTICO}

La esterilidad afecta a casi un $20 \%$ de las parejas en edad reproductiva y en la mitad de los casos el factor masculino tiene un papel relevante. Entre los parámetros clásicos que determinan una buena calidad seminal, tales como, la motilidad espermática, la morfología o el estado de los acrosomas y de las membranas, la integridad de la molécula de DNA es crucial para llevar a cabo una fecundación con éxito. Sin embargo, el estudio de este último parámetro no es sencillo, hecho que ha dificultado su incorporación rutinaria en la elaboración de los seminogramas. La presente revisión tiene dos objetivos: 1) presentar una visión actualizada de aquellas tecnologías que se consideran más eficaces para el estudio de la fragmentación del DNA en el espermatozoide, teniendo en cuenta la posibilidad de su uso en los laboratorios de andrología y de acuerdo con la complejidad intrínseca al proceso, el equipamiento y los recursos disponibles, y 2) analizar sus efectos e implicaciones sobre la fecundación, desarrollo embrionario y fertilidad.

Palabras clave: Fragmentación del DNA en espermatozoides. Esterilidad masculina. Fertilidad. Calidad seminal.

\section{ABSTRACT}

\section{ASSESSING SPERM DNA DAMAGE}

Infertility affects almost $20 \%$ of couples in reproductive age and the male factor being responsible of $50 \%$ of this infertility. Among the classic parameters that determine a good seminal quality such as sperm motility, sperm morphology or the quality of the of acrosomes and/or sperm membranes, the integrity of the DNA molecule is crucial to carry out a successful fertilization. Nevertheless, the study of this parameter has not been straightforward approached. This fact has shunned its incorporation, as a routine technique, within a standard seminogram. The aim of the present review is to summarize and update those technologies that are considered more successful to study sperm DNA fragmentation with special emphasis to: 1) the levels of technological complexity and the possibility of its use in laboratories of andrology, according with the equipment and the resources available, and 2) the effects and possible implications of high level of sperm DNA fragmentation for fecundation, embryo development and fertility.

Keywords: Sperm DNA fragmentation. Male sterility. Fertility. Semen quality.

$\mathrm{L}$ a esterilidad afecta a casi un $20 \%$ de las parejas en edad reproductiva. Esta cifra está aumentando de modo acelerado en los últimos años, debido a un cambio radical en las pautas sociales del ser humano. Parece ser que el fenómeno afecta a ambos sexos, de tal forma que el factor masculino parece estar involucrado en la mitad de los casos de infertilidad ${ }^{1}$.
$\mathrm{El}$ análisis de las características de muestras seminales es esencial para evaluar si el factor masculino tiene influencia en la infertilidad. Para el estudio de la infertilidad masculina relacionada con la calidad del semen, la Organización Mundial de la Salud ${ }^{2}$, ha establecido una serie de parámetros que se debieran analizar de forma rutinaria en un laboratorio básico de andrología. 
Entre las características clásicas que se determinan de modo habitual, destacan el volumen del eyaculado, el pH, el número de espermatozoides por unidad de volumen, la motilidad y la morfología de los espermatozoides. En general y para cada parámetro analizado, se establecen valores umbral, tanto para el estudio de caracteres cualitativos como cuantitativos. Sin embargo, aún utilizando este tipo de valores, se estima que aproximadamente un $15 \%$ de los varones estériles presentan un espermiograma normal ${ }^{3}$. Por lo tanto, es verosímil que estos parámetros no sean del todo indicativos de la calidad de los espermatozoides presentes en una muestra seminal. Adicionalmente, al añadir otro tipo de parámetros tales como la integridad del acrosoma, la vitalidad, la evaluación de ciertas actividades enzimáticas o la integridad funcional de la membrana, la conclusión que se alcanza es que ningún parámetro, per se, se puede considerar de valor diagnóstico absoluto de la infertilidad masculina. La situación es todavía más crítica cuando se utilizan técnicas de reproducción asistida. En este tipo de situaciones, donde se recurre a la fertilización in vitro (FIV) o bien a la inyección del espermatozoide en el citoplasma del ovocito (ICSI), la calidad de los espermatozoides que se utilizan, requiere un control mucho más delicado que en el caso de la reproducción normal. Esto es debido, por una parte, a las manipulaciones técnicas que implican este tipo de procesos y por otra, al simple hecho de que la necesidad de recurrir a esta clase de técnicas lleva implícito que puede existir algún problema que interfiere con la concepción normal ${ }^{4}$.

Parece lógico asumir que la transferencia de la molécula del DNA integra e intacta desde el espermatozoide al óvulo, es crucial para conseguir una fecundación con ciertas perspectivas de éxito. Sin embargo, resulta sorprendente que no exista una tecnología rápida para analizar la calidad del DNA en una célula tan crítica como el espermatozoide y que se pudiera utilizar con la misma facilidad con la que se procede para estudiar, por ejemplo, la motilidad de estas mismas células. En este sentido, es bien conocido que la presencia de defectos en el material genético, tales como anomalías en la condensación de la cromatina, en relación con el proceso de la maduración del espermatozoide, la integridad de la molécula de DNA asociada con la presencia de roturas tanto de doble cadena como de cadena sencilla del DNA, o la presencia de anomalías cromosómicas, como pueden ser las aneuploidías o las reordenaciones genómicas estructurales, se asocian estrechamente con la infertilidad ${ }^{5}$. Sin embargo, no existe una tecnología adecuada que traspase el ámbito de la investigación y que se pueda utilizar de forma sistemática en un servicio básico de andrología.

En lo que se refiere al origen del daño en el DNA del espermatozoide, nos enfrentamos con toda seguridad a un efecto de naturaleza multifactorial en el que interviene una casuística no del todo delimitada. Se sabe que la generación de radicales libres de oxígeno (ROS) ${ }^{6}$ o bien fallos en el intercambio correcto de la fracción histónica de la cromatina por las protaminas, pueden producir daño irreversible en el DNA del gameto. En relación directa con este tipo de acontecimientos, la presencia de apoptosis, como un suceso de muerte celular programada, tiene lugar durante el proceso de maduración espermática ${ }^{7,8}$. No obstante, es interesante destacar que la incidencia del fenómeno apoptótico en los espermatozoides de un eyaculado que se manipula para un proceso de reproducción asistida, generaría una serie de metabolitos que no serán retirados por tipos celulares tales como los macrófagos, hecho que ocurriría en cualquier muerte celular en el nivel somático. Esta situación puede generar un acumulo no deseable de metabolitos altamente reactivos, tales como enzimas celulares, enzimas procedentes del acrosoma o bien nucleasas de remodelación de la cromatina tales como la topoisomerasa. Todo este tipo de acción enzimática "fuera de control" puede contribuir e incluso acelerar el proceso de degradación celular, afectando de forma indirecta, a otros espermatozoides. En este escenario, se ha sugerido que el daño provocado en la molécula del DNA del espermatozoide por razones de distinta naturaleza, puede afectar la salud del embrión, la del feto e incluso la de la descendencia global ${ }^{9,10}$. Además, se ha propuesto que el efecto de este daño puede asociarse a enfermedades que aparecen en la descendencia, tales como la propia infertilidad ${ }^{11,12}$, la presencia de cáncer en la niñez ${ }^{13}$ o bien puede relacionarse 
con ciertas enfermedades de impronta genómica anormal $^{14}$. Adicionalmente, existen causas de naturaleza exógena a la propia dinámica de formación del gameto tras el proceso meiótico, que resultan en un incremento notable en el daño que se observa en el DNA de un espermatozoide. De esta forma, el uso de ciertos fármacos, la contaminación atmosférica, el tabaquismo, los episodios de fiebre alta, una temperatura testicular elevada, anomalías anatómicas tales como el varicocele, o una edad avanzada, contribuyen de forma notable a incrementar las tasas de daño registrado en el DNA del espermatozoide ${ }^{13,15-17}$.

$\mathrm{El}$ propósito de la presente revisión es presentar una recopilación actualizada de aquellas tecnologías que consideramos más eficaces para el estudio de la fragmentación del DNA en el espermatozoide, teniendo en cuenta sus niveles de complejidad y la posibilidad de su uso en distintos laboratorios de andrología, de acuerdo con el equipamiento y recurso disponibles. De forma paralela, esta revisión intenta resaltar los efectos e implicaciones de la fragmentación del DNA en los espermatozoides y en qué situaciones clínicas una muestra de semen puede presentar unos niveles elevados de daño en la molécula de DNA.

\section{METODOLOGIAS PARA LA DETECCIÓN DEL DAÑO EN DNA DEL ESPERMATOZOIDE}

Existen dos estrategias diferentes para estudiar la fragmentación del DNA espermático (Tabla 1). La primera, incluye aquellas metodologías encaminadas a marcar las roturas, tanto de cadena sencilla como de cadena doble, que se registran de forma natural o fortuita en la molécula de DNA. Dentro de este grupo, podríamos incluir el uso de procesos enzimáticos para la incorporación in situ de nucleótidos marcados, tales como la Terminal dUTP Nick-End Labeling (TUNEL) ${ }^{18}$ o la In Situ Nick Translation (ISNT) ${ }^{19,20}$. Dado que las roturas del DNA incrementan la susceptibilidad del DNA a la desnaturalización, al iniciarse esta a partir de los extremos de la rotura, la segunda estrategia incluye aquellas tecnologias que miden la distinta capacidad de la cromatina y en particular del DNA, para desnaturalizarse frente a determinados tratamientos. En este grupo se incluyen técnicas tales como el Sperm Chromatin
Structure Assay $(\mathrm{SCSA})^{21}$, el DNA Breakage Detection-Fluorescence In Situ Hybridization (DBD-FISH), una metodología que utiliza la hibridación in situ de ácidos nucleicos ${ }^{22}$, el ensayo cometa bajo condiciones desnaturalizantes ${ }^{23}$, o la prueba Sperm Chromatin Dispersion (SCD) ${ }^{24}$. Adicionalmente, existen otras pruebas para el análisis del estado de la cromatina en el espermatozoide que comentaremos con menor detalle debido a que no son tan utilizadas, o bien en algunos casos, son controvertidas.

\section{Ensayo TUNEL (Terminal dUTP Nick-End Labeling)}

Esta prueba permite visualizar la incorporación de nucleótidos marcados en los extremos de las roturas existentes en el DNA, bien sean de cadena simple o doble. La reacción se cataliza, in situ, mediante la acción de una transferasa terminal. Esta enzima incorpora deoxiuridina modificada con biotina o digoxigenina, en el extremo 3'-OH de la cadena afectada. Posteriormente, los nucleótidos modificados se detectan tras una reacción con un anticuerpo conjugado con un fluorocromo como molécula trazadora. El nucleótido incorporado puede estar directamente marcado con el fluorocromo. Teóricamente, la señal de marcado obtenida por cada espermatozoide, se incrementaría de acuerdo con el número de roturas que presente la cadena de DNA ${ }^{18,25}$.

La técnica ha tenido una buena aceptación dado que es versátil, esta comercializada en kit y los resultados pueden ser interpretados mediante microscopía de fluorescencia y citometría de flujo. Según algún estudio de evaluación visual directa, la variabilidad intraobservador es menor del $8 \%$ y la interobservador es menor del $7 \%{ }^{26}$. De todos modos, existen niveles de marcado intermedio de la molécula de DNA e irregulares, o bien niveles de base variables, que pueden presentar cierta confusión. Su uso no se ha expandido en la rutina clínica por tres razones:

1) Requiere equipo sofisticado para su análisis.

2) Requiere personal especializado

3) El material que se utiliza viene precedido por un proceso de fijación de la cromatina que puede dificultar el acceso de las enzimas y la propia actividad enzimática puede ser irregular. 
Tabla 1

Resumen de las metodologías utilizadas para evaluar alteraciones en el DNA de espermatozoides, así como de algunas de sus ventajas e inconvenientes en relación con la aplicación clínica de rutina

\begin{tabular}{|c|c|c|c|c|}
\hline \multicolumn{5}{|c|}{ Metodologias que se basan en el marcaje de roturas del DNA } \\
\hline Método & Instrumental & Ventajas & Desventajas & Utilidad clinica \\
\hline TUNEL & $\begin{array}{l}\text { Microscopio Fluorescencia } \\
\text { Citometría de flujo }\end{array}$ & $\begin{array}{l}\text { Cumple con parámetros de control } \\
\text { de calidad }\end{array}$ & Equipo sofisticado y costoso & $\begin{array}{l}\text { Fertilidad masculina } \\
\text { Reproducción asistida } \\
\text { Pérdidas fetales }\end{array}$ \\
\hline ISNT & $\begin{array}{l}\text { Microscopio Fluorescencia } \\
\text { Citometría de flujo }\end{array}$ & Reacción de marcaje directo & Equipo sofisticado y costoso & Fertilidad masculina \\
\hline \multicolumn{5}{|c|}{ Metodologias que se basan en la susceptibilidad del DNA para desnaturalizarse } \\
\hline SCSA & Citometría de flujo & $\begin{array}{l}\text { Punto de corte establecido ( } 30 \%) \\
\text { para diferenciar pacientes fértiles } \\
\text { e infértiles }\end{array}$ & $\begin{array}{l}\text { Instrumentación costosa } \\
\text { Capacitación técnica }\end{array}$ & $\begin{array}{l}\text { Recomendada en estudios } \\
\text { epidemiológicos de infertilidad }\end{array}$ \\
\hline COMETA & $\begin{array}{l}\text { Microscopio Fluorescencia } \\
\text { Electroforésis DNA }\end{array}$ & Bajo costo & $\begin{array}{l}\text { Lento de ejecución } \\
\text { Requiere observador con } \\
\text { experiencia }\end{array}$ & $\begin{array}{l}\text { Fertilidad masculina } \\
\text { Reproducción asistida } \\
\text { Criopreservación de esperma }\end{array}$ \\
\hline $\mathrm{SCD}$ & $\begin{array}{l}\text { Microscopio Fluorescencia } \\
\text { campo claro }\end{array}$ & $\begin{array}{l}\text { Análisis simple de resultados } \\
\text { Bajo costo }\end{array}$ & Aún no determinada & $\begin{array}{l}\text { Aún no determinada } \\
\text { Varicocele? }\end{array}$ \\
\hline DBD-FISH & Microscopio Fluorescencia & $\begin{array}{l}\text { Revela modificaciones estructurales } \\
\text { de la cromatina. }\end{array}$ & $\begin{array}{l}\text { Procedimiento sofisticado } \\
\text { y costoso }\end{array}$ & Aún no determinada \\
\hline \multicolumn{5}{|c|}{ Otros métodos } \\
\hline NA & $\begin{array}{l}\text { Microscopio Fluorescencia } \\
\text { Citometría de flujo }\end{array}$ & Bajo costo & $\begin{array}{l}\text { Subjetiva } \\
\text { Poco reproducible }\end{array}$ & $\begin{array}{l}\text { Diferencias significativas en } \\
\text { patologías andrológicas }\end{array}$ \\
\hline AT & Microscopio campo claro & $\begin{array}{l}\text { Método simple y } \\
\text { de bajo costo }\end{array}$ & $\begin{array}{l}\text { Subjetiva } \\
\text { Poco reproducible }\end{array}$ & $\begin{array}{l}\text { Evaluación de anormalidades } \\
\text { en la cromatina. }\end{array}$ \\
\hline CMA & Microscopio Fluorescencia & $\begin{array}{l}\text { Método simple y } \\
\text { de bajo costo }\end{array}$ & $\begin{array}{l}\text { Subjetiva } \\
\text { Poco reproducible }\end{array}$ & $\begin{array}{l}\text { Evaluación de anormalidades } \\
\text { en la cromatina. }\end{array}$ \\
\hline
\end{tabular}

TUNEL: Terminal dUTP Nick-End Labeling. ISNT = In situ Nick Translation. DBD-FISH: DNA Breakage Detection-Fluorescence In Situ Hybridization. SCSA: Sperm Chromatin Structure Assay. SCD: Sperm Chromatin Dispersion. NA: Naranja de Acridina. AT= Azul de Toluidina. CMA: Cromomicina A3.

\section{Prueba de ISNT (In Situ Nick Translation)}

La ISNT es básicamente una técnica de concepción similar al TUNEL ya que permite cuantificar el grado de daño que se produce en el DNA evaluando tras la incorporación de moléculas de dUTP modificado con botina o digoxigenina, o bien marcado directamente el DNA con un fluorocromo conjugado con un nucleótido modificado, tras utilizar la enzima DNA polimerasa I. La mayor diferencia con el TUNEL radica en que, en este caso, existe una actividad enzimática exonucleasa y la incorporación de nucleótidos es mayor por utilizar la cadena de DNA complementaria como molde. Los resultados del análisis de ISNT se han utilizado para el estudio de la presencia de anomalías originadas durante la remodelación de la cromatina del espermatozoide ${ }^{27}$. Desde el punto de vista práctico, esta técnica tendría las mismas prestaciones e inconvenientes que la de TUNEL, pero no existe disponible de modo comercial para su aplicación directa sobre espermatozoides.

\section{DBD-FISH (DNA Breakage Detection- \\ Fluorescence In Situ Hybridization)}

Se trata de una metodología relativamente reciente y que se circunscribe al campo de la investigación. Se fundamenta en la capacidad que tienen ciertas soluciones alcalinas de producir una desnaturalización del DNA a partir de los extremos de roturas de doble cadena o de cadena sencilla, o bien lugares sensibles al álcali. Después de la des- 
naturalización y extracción de las proteínas utilizando una solución de lisis, el DNA generado de cadena sencilla, puede hibridarse con una sonda de DNA (Fig. 1). Cuantas más roturas existan en dicha cadena, mayor será el nivel de marcado que se obtenga en el núcleo ${ }^{22}$. Al igual que las técnicas de TUNEL o ISNT, la técnica de DBD-FISH no se puede considerar de aplicación rutinaria por razones similares a las descritas previamente. Desde el punto de vista de la investigación, tiene mucho interés, ya que es la única técnica disponible que nos permite evaluar daño de célula a célula, in situ, en secuencias específicas del DNA ${ }^{28}$.

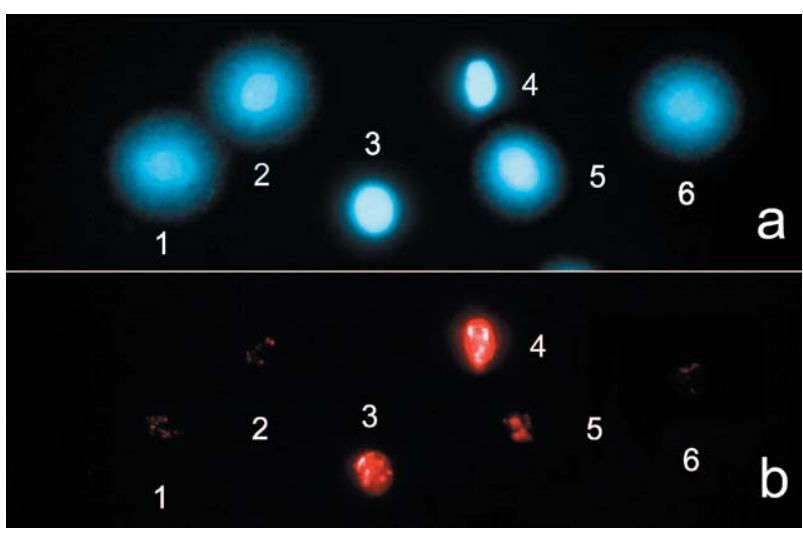

FIGURA 1. Visualización de la integridad del DNA mediante el método de SCD (Sperm Chromatin Dispersión) combinado con DBD-FISH (DNA Breakage Detection-FISH). 1a. Los halos de dispersión de la cromatina muestran espermatozoides con su DNA integro (núcleos 1,2,5,6), mientras que los que no presentan halo o este es de tamaño reducido, contienen DNA fragmentado (núcleos 3,4). Tinción DAPI. 1b. Representa el mismo campo que la figura 1 a tras DBD-FISH. Tan sólo los espermatozoides etiquetados como 3 y 4 muestran una clara señal de hibridación, es decir, con roturas del DNA.

\section{Ensayo del cometa}

En realidad este ensayo es una adaptación de la electroforesis de DNA desnudo, comúnmente utilizada en biología molecular, al campo de la biología celular. La idea es que el DNA de un núcleo desproteinizado que contenga roturas en sus cadenas de DNA, estará mas libre para ser movilizado hacia el polo positivo, cuando éste se someta a un campo eléctrico ${ }^{5}$. La metodología básica consiste en incluir una muestra de espermatozoides en un microgel de agarosa sobre un portaobjetos y someterlo a una solución de lisis que contenga un agente reductor de los grupos sulfidrilo que se encuentran en la protaminas del espermatozoide, como por ejemplo DTT (dithiothreitol). Tras la electroforesis, el microgel se tiñe con sustancias fluorescentes del tipo DAPI (4,6 diamidino-2-phenylindole), IP (Ioduro de Propidio) o SYBR-GREEN (Synergy Brand). De esta forma, el DNA fragmentado se desplaza generando una imagen similar a la de un cometa (Fig. 2). Aquellos espermatozoides con su DNA integro no generan o sólo producen imágenes de discretas colas de cometa, mientras que aquellos núcleos que tienen su DNA dañado muestran un claro desplazamiento de los múltiples fragmentos de $\mathrm{DNA}^{23}$ (Fig. 2). Al igual que las pruebas anteriores, esta técnica se aplica en investigación y se puede adaptar de forma sencilla para el análisis de muestras de semen de otras especies ${ }^{29,30}$. El mayor inconveniente de este ensayo es que requiere un material de uso no común en un laboratorio de andrología, como son fuentes de electroforesis para DNA, y para la interpretación de los resultados se requiere un observador con experiencia o bien un software específico para que la prueba tenga cierta objetividad.

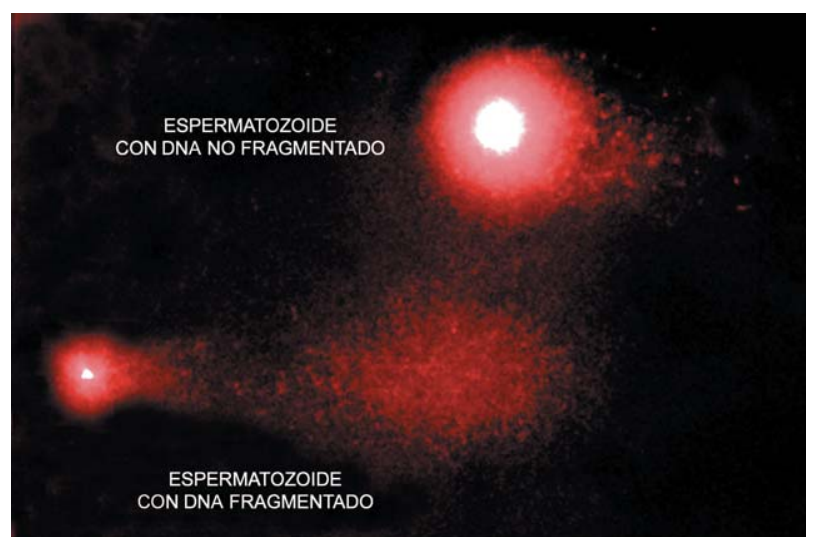

FIGURA 2. Visualización de la integridad del DNA mediante el ensayo de cometas. Los espermatozoides que presentan DNA fragmentado (parte inferior de la figura) muestran un claro desplazamiento de los fragmentos de DNA al ser sometidos a la acción de un campo eléctrico. Este no se aprecia en los núcleos que mantienen el DNA integro (parte superior de la figura).

\section{SCSA (Sperm Chromatin Structure Assay)}

La técnica desarrollada por Evenson et al. ${ }^{21}$ hace ahora casi 25 años, se viene considerando como el referente para el análisis de la fragmentación del DNA en el espermatozoide. Su aplicación está relativamente extendida en humanos y también 
ofrece buenos resultados en animales utilizados para explotación ganadera, tales como ganado porcino y bovino. El principio en el que se sustenta la técnica es que la cromatina que presenta DNA fragmentado tiene mayor susceptibilidad para ser desnaturalizada in situ tras aplicar un tratamiento con calor o una solución ácida. La segunda parte de la metodología se fundamenta en las características metacromáticas de la naranja de acridina. Este fluorocromo tiene la capacidad de intercalarse entre las dos cadenas de DNA como un monómero, que al ser excitado emite color verde, pero que presenta emisión en color rojo-anaranjado si se incorpora al DNA de cadena sencilla. Las células asî teñidas se someten a citometría de flujo para discriminar entre ambos tipos de color ${ }^{31}$. Esta técnica es la más aceptada para establecer correlaciones entre fragmentación de DNA y fertilidad de un individuo. El grupo del Dr. Evenson ha establecido que individuos con un porcentaje de fragmentación en su DNA de alrededor de un 30\% o superior, presentaría problemas de fertilidad ${ }^{32}$. El inconveniente que tiene esta tecnología es que no es accesible a la mayoría de los laboratorios, ya que al fundamentarse en la utilización de la citometría de flujo, restringe su uso por las razones comentadas anteriormente para otras tecnologias.

\section{Test SCD (Sperm Chromatin Dispersion)}

Desde que Calvin y Bedford en $1971^{33}$ relata- ron el papel que juegan los puentes disulfuro en la compactación de la cromatina de los espermatozoides y las diferencias que existen con respecto a la línea somática ${ }^{34,35}$, el análisis de la estructura de la cromatina espermática experimentó un enorme avance. El DNA del espermatozoide se encuentra unas seis veces mas compactado que el del cromosoma mitótico. Este DNA se encuentra organizado en bucles de menor tamaño que los de las células somáticas, anclados a la matriz nuclear. Dichos bucles se compactan por la acción de las protaminas intercaladas, las cuales estabilizan rígidamente la estructura a través de la formación de puentes disulfuro entre ellas. Si se rompen los enlaces disulfuro y se usa una solución específica de lisis para extraer proteínas, los bucles de DNA se relajan constituyendo halos alrededor de la estructura nuclear central residual. Se ha comprobado que, tras un tratamiento ácido previo, aquellos espermatozoides con DNA fragmentado no sueltan o ven impedida en gran medida la liberación de los bucles de DNA, mostrando halos muy reducidos o ausencia de los mismos, al contrario que los espermatozoides sin fragmentación de $\mathrm{DNA}^{24}$. Simplemente valorando el tamaño de los halos de dispersión de la cromatina, mediante microscopia tanto de campo claro como de fluorescencia, es posible reconocer la presencia de fragmentación de DNA en los espermatozoides humanos ${ }^{36}$ (Fig. 3). Esta
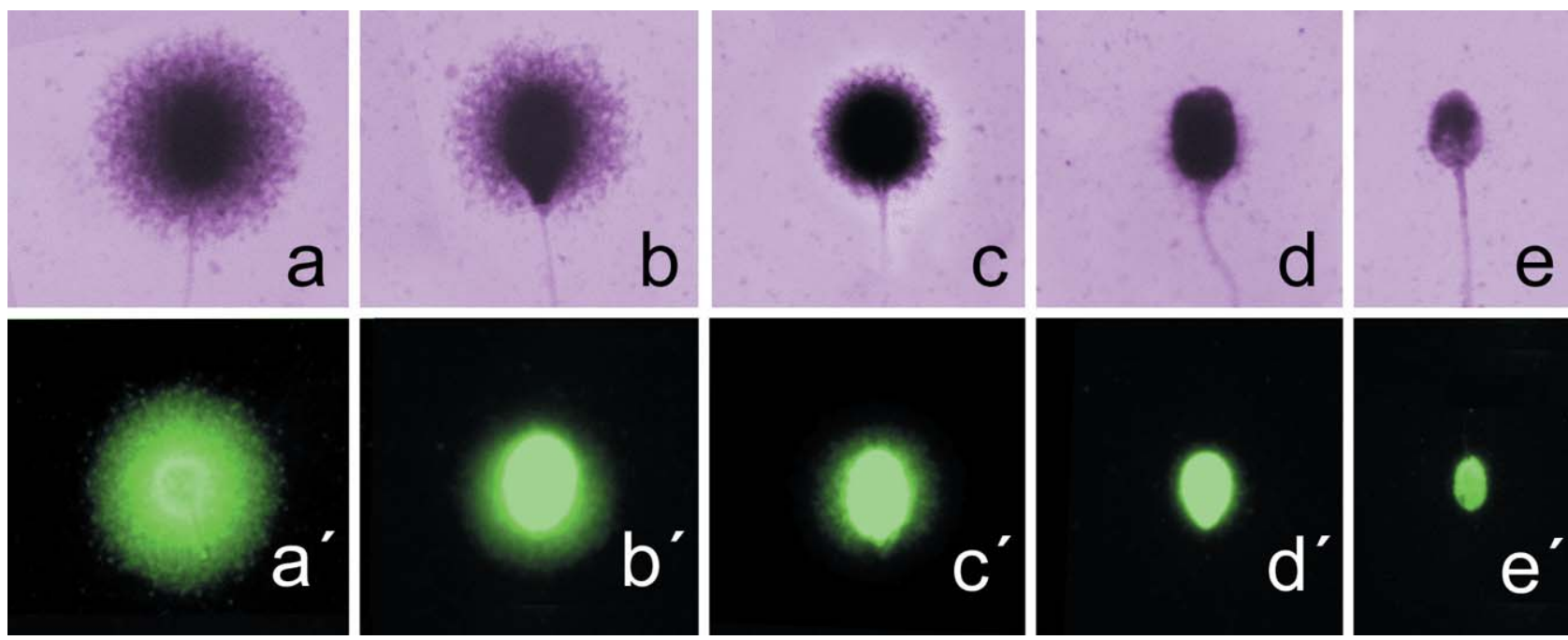

FIGURA 3. Visualización de la integridad del DNA mediante el test SCD (Sperm Chromatin Dispersion) y visualización en microscopía de campo claro (a-e; tinción: colorante de Wright) y microscopia de fluorescencia ( $a^{\prime}-e^{\prime}:$ tinción SYBR-Green). Mientras que los espermatozoides etiquetados como a y $b$, tienen su DNA integro, el resto presentan DNA fragmentado (ver DBD-FISH). 
valoración puede ser automatizada, empleando programas informáticos asociados a sistemas tipo CASA (Computer Assisted Sperm Analyzer). La técnica, al igual que ocurre en el caso del ensayo cometa, requiere que los espermatozoides se incluyan en microgeles de agarosa, pero sin electroforesis, con lo cual el método se simplifica notablemente. La principal ventaja de esta técnica es que la interpretación de los resultados no requiere la determinación de color, ni de intensidad de fluorescencia y no necesita de un equipo complejo, ni personal especializado.

Los resultados preliminares de esta prueba, muestran una correlación con otras metodologías, tales como el SCSA o el TUNEL ${ }^{25,36}$. Además existe una versión comercial del producto que facilita su uso en laboratorios básicos. La prueba SCD se ha ensayado con éxito para la determinación de la fragmentación del DNA en otras especies, tales como ratón y ganado porcino ${ }^{37,38}$. Dada su sencillez y no requerimiento de ningún equipo no convencional, se ha propuesto que la técnica SCD puede ser potencialmente utilizada como prueba de rutina en el estudio de fragmentación de DNA espermático en los laboratorios básicos de andrología.

\section{METODOLOGIAS ALTERNATIVAS}

Prueba de naranja de acridina

Utilizando las propiedades metacromáticas de la naranja de acridina, algunos investigadores han aplicado el mismo principio que el utilizado en el SCSA para visualizar los espermatozoides con DNA fragmentado empleando microscopía de fluorescencia ${ }^{39-41}$. El mayor problema de esta técnica es el componente de la subjetividad del observador en el momento de discriminar entre la emisión del color verde y el naranja de este fluorocromo, dado que existe toda una serie de colores intermedios que probablemente se relacionan con una sensibilidad diferencial a la desnaturalización de los distintos espermatozoides. Además los resultados no parecen muy reproducibles, ya que parecen variar con el tiempo, y no distingue entre pacientes infértiles y donantes ${ }^{25}$.

Azul de Toluidina

El azul de Toluidina es un colorante nuclear básico que genera reacciones metacromáticas cuando interacciona con la cromatina. Cuando este colorante se incorpora en cromatina rica en histonas, con abundancia de lisina, presenta una coloración violeta-azulada intensa, mientras que cuando lo hace a cromatina rica en protaminas presenta una coloración azul-pálida ${ }^{42}$. Se trataría, en realidad, de una prueba de maduracióncondensación nuclear, y los espermatozoides con cromatina inmadura tendrían más habitualmente roturas del DNA. La técnica es simple y de un bajo coste y tiene la ventaja de proporcionar preparaciones permanentes para su uso en un microscopio ordinario, aunque las tinciones intermedias son de difícil valoración. El análisis de los resultados también puede realizarse en citometría de flujo $^{43}$, con los inconvenientes ya mencionados. Desafortunadamente, los resultados son poco reproducibles ${ }^{26}$.

\section{Cromomicina A3 (CMA3)}

La Cromomicina A3 es un fluorocromo ampliamente utilizado en citogenética debido a que produce una buena diferenciación longitudinal de los cromosomas, ya que se ancla específicamente a regiones ricas en guanina-citosina y compite por los mismos lugares en el DNA, que las protaminas. Por lo tanto, cuando los espermatozoides presentan una tinción intensa tras ser teñidos con CMA3, se interpreta que esta población celular muestra unos niveles bajos de protaminación. Es decir, esta técnica revela espermatozoides que tienen un nivel deficiente de empaquetamiento en su cromatina ${ }^{20}$, siendo también una prueba de maduración-condensación nuclear. De nuevo, una de las limitaciones más importantes de esta técnica es la subjetividad del observador a la hora de establecer los grupos de clasificación. No obstante, algunos estudios la muestran como una prueba de elección frente a la naranja de acridina, o derivados de la toluidina, para el análisis de la maduración nuclear del espermatozoide ${ }^{44}$.

\section{SIGNIFICADO CLÍNICO DEL DAÑO EN EL DNA DEL ESPERMATOZOIDE}

La calidad de la cromatina en el espermatozoide está siendo considerada como un nuevo parámetro de calidad seminal, con posible relación con la fertilidad del individuo. Existen evi- 
dencias que indican que la integridad del DNA espermático se relaciona con la fertilidad de una pareja y ayuda a predecir las oportunidades de embarazo y de éxito de éstos ${ }^{5}$. En concepción natural, diversos estudios indican un impacto significativo del daño del DNA espermático en la fertilización. De esta forma, tanto los datos obtenidos con la técnica de TUNEL como con el SCSA, ofrecen diferencias significativas en los niveles del daño en el DNA del esperma entre varones que se consideran fértiles y aquellos que se consideran estériles ${ }^{45-47}$. El nivel de corte para los valores de fragmentación del DNA propuesto por Evenson, establece que la probabilidad de la fertilización in vivo es cercana a cero si la proporción de espermatozoides con daño excede el $30 \% 32,48$. Aunque el establecimiento de unas cifras umbral para predecir la fertilidad es discutido por otros autores, existe la convicción de que la calidad seminal, la capacidad de fertilización, la calidad del embrión y el desarrollo hasta blastocisto, se ven influenciados por la frecuencia de espermatozoides con DNA fragmentado presentes en la muestra ${ }^{49}$.

Habría que señalar que la fragmentación del DNA no parece tener una correlación plena con ninguno de los parámetros clásicos de calidad seminal que se analizan para estimar la capacidad fertilizante de un individuo. Por lo tanto, se aconseja su estudio con el fin de tener una visión más completa de la calidad seminal. El índice de fragmentación del DNA, evaluado mediante la técnica SCSA, presenta una débil o moderada correlación con los criterios clásicos de calidad espermática ${ }^{50,51}$. Sin embargo, mediante la prueba TUNEL y ensayo cometa se ha demostrado una correlación inversa entre el porcentaje de espermatozoides con DNA fragmentado, la motilidad, la concentración y los parámetros morfológicos relacionados con formas anormales ${ }^{52}$. El daño en el DNA, evaluado mediante SCD, muestra un incremento significativo de este parámetro en pacientes con oligoastenoteratozoospermia $(47,1 \% \pm 17,3)$ y en pacientes normozoopérmicos $(27,3 \% \pm 11,7)$, frente a individuos fértiles $(16,3 \% \pm 6,0)^{36}$. Sin embargo, el establecimiento de una correlación entre un alto grado de fragmentación en el DNA espermático y ausencia de embarazo, no se ha llegado a establecer de forma absoluta, siendo discutida por diversos autores ${ }^{53}$. Obviamente, la capacidad que presenta el oocito para reparar el DNA dañado, también debe ser considerada. Posiblemente este problema subyazca con cierta frecuencia en las infertilidades mixtas. Dado el nivel actual de conocimiento, lo más sensato es tratar la fragmentación del DNA en el contexto global del seminograma, como un parámetro adicional que complementaría el estudio del semen, para obtener una visión mucho más completa de la situación particular de cada individuo.

\section{LA FRAGMENTACIÓN DEL DNA EN LA CLÍNICA DIARIA}

Las prácticas de reproducción asistida (inseminación intrauterina, fertilización in vitro o inyección espermática intracitoplasmática en el oocito), requieren una selección artificial previa de las muestras de semen, lo que podría provocar cierto daño en el DNA de los espermatozoides, incluso aquellos que se evalúan como normales por su apariencia morfológica, podrían tener un daño no detectable. Esta situación es particularmente crítica en pacientes sometidos a una selección de espermatozoides rigurosa para ser incluidos en programas de ICSI. La centrifugación de muestras de semen con gran proporción de espermatozoides inmaduros, que producen altos niveles de ROS, puede resultar en incremento del daño al resto de espermatozoides ${ }^{54,55}$. Los procesos de congelación-descongelación no parece que afecten al nivel de fragmentación en los individuos fértiles. Sin embargo, esto puede no ser así con los espermatozoides de los individuos infértiles ${ }^{56}$. En general, las tasas de éxito tras ICSI se mantienen en un rango superior a un $65 \%{ }^{57}$, pero, quizás, si se consiguiesen espermatozoides y por supuesto oocitos de mayor calidad, estos rangos de eficacia podrían verse mejorados.

Diversos estudios parecen indicar que la valoración de la fragmentación del DNA de los espermatozoides es más predictiva de consecución de embarazo al aplicar técnicas de FIV que en el ICSI $^{58-60}$. En la inseminación intrauterina, utilizando la técnica de TUNEL para la valoración de la fragmentación del DNA, se ha comprobado que, en muestras de semen que contienen más del $12 \%$ de espermatozoides con DNA fragmentado, las posibilidades de lograr un embarazo dis- 
minuyen de manera drástica ${ }^{61}$. Asímismo, se ha comprobado que la probabilidad de conseguir un embarazo tras ICSI, también es mucho más problemática si la proporción de espermatozoides con daño en el DNA excede el 30\%62,63.

Ciertos trabajos empleando el SCSA, sugieren que la oportunidad de embarazo después de FIV o ICSI es significativamente mayor cuando el índice de fragmentación es menor al $27 \%{ }^{60,64}$. En el caso de la utilización de ISCI y utilizando pruebas de ISNT, TUNEL y ensayo de cometas, se han encontrado correlaciones negativas entre el daño del DNA espermático y la fertilización del oocito, la calidad del embrión ${ }^{7}$ y el desarrollo hasta blastocisto $^{64,65}$, así como con la implantación del embrión $^{66}$. Recientemente, la determinación de la fragmentación del DNA mediante la técnica SCD ha demostrado una correlación con todos estos parámetros ${ }^{67}$. Ciertos resultados parecen indicar que la incidencia de la fragmentación del DNA espermático puede tener especial relevancia en las pérdidas embrionarias. Cuando ocurre la fertilización con un espermatozoide que presenta daño en su DNA, la habilidad del oocito para repararlo depende de la severidad de dicho daño ${ }^{68}$. Por lo tanto, el desarrollo embrionario puede fallar en cualquier etapa o llegar a término con ciertas anomalías. Se ha demostrado que la proporción de espermatozoides con DNA fragmentado, detectado mediante TUNEL, es significativamente más alta en varones de parejas con abortos recurrentes $(38,0 \pm 4,2 \%)$, comparado con la de la población general $(22,0 \pm 2,0 \%)$ o con la de donantes fértiles $(11,9 \pm 1,0 \%)^{69}$. Además, se ha señalado que un índice de fragmentación de DNA de espermatozoides mayor del 30\% (evaluado mediante SCSA) se asocia no sólo con índices bajos de embarazo, si no también con pérdidas fetales $^{4}$. A pesar de estos trabajos, los datos sobre la posible relación entre la fragmentación del DNA de los espermatozoides y el desarrollo de abortos espontáneos, tanto aislados como de repetición, son escasos y por lo tanto no se pueden considerar que sean concluyentes ${ }^{4,63,70,71}$. Sin embargo, este puede ser unos de los campos donde la fragmentación del DNA puede tener una relación muy clara y directa con un efecto determinado.

Un tipo diferente de contexto clínico es el que afecta a pacientes con cáncer. En estas situacio- nes, donde con frecuencia se tiene que recurrir a tratamientos de quimio o radioterapia, la probabilidad que estos pacientes dejen descendencia, es muy baja cuando están sometidos a tratamiento. Una de las razones que podría explicar este hecho, se relaciona con un mayor nivel de fragmentación del DNA espermático que experimentan este tipo de pacientes, al ser comparados con grupos control ${ }^{72}$. En estos pacientes, surge la necesidad de criopreservar espermatozoides, con bajos niveles de daño del DNA, para su posible uso en programas de reproducción asistida ${ }^{26}$.

La técnica de SCD ha demostrado recientemente que los individuos con varicocele, si bien pueden tener un nivel de fragmentación más alto que los fértiles, éste no tiene porqué ser diferente del resto de los infértiles. Sin embargo, el perfil de distribución de las categorías de daño es peculiar. De cada 4 espermatozoides con DNA fragmentado, uno es de tipo degradado. Es decir, con el nivel más alto de daño en el DNA. Sin embargo, en el resto de grupos, fértiles e infértiles, la proporción es de un espermatozoide degradado por cada 8-9 fragmentados ${ }^{17}$. Quizás esta situación podría ser un marcador que ayudase al clínico a sospechar la presencia de varicocele, aunque no deben descartarse otras posibles patologías crónicas.

Las patologías infecciosas también pueden tener repercusión a este nivel. Algunos estudios recientes sugieren que las infecciones por ciertas cepas de microorganismos podrian afectar a la integridad del DNA. La incubación de muestras de semen con Escherichia coli o con Staphylococcus aureus parece inducir una mayor frecuencia de espermatozoides con localización de fosfatidilserina en la cara externa de la membrana plasmática. Situación que se suele asociar con la apoptosis. La técnica de TUNEL ha demostrado un incremento de los niveles de fragmentación, tras co-incubar espermatozoides con cuerpos elementales de Chlamydia trachomatis ${ }^{73}$. Finalmente, la incubación con DNA de los papilomavirus tipo 16 y 31, también incrementó los niveles de fragmentación del DNA, medidos tras un ensayo de $\operatorname{cometas}^{74}$.

\section{CONCLUSIONES}

La evidencia en la literatura demuestra que el daño del DNA en los espermatozoides afecta el 
resultado de la fertilidad de tal forma que, un semen que presente una frecuencia alta de espermatozoides con DNA fragmentado tendría mayor dificultad para producir un embarazo, que un semen con bajo nivel de fragmentación. Debido a que la presencia de DNA fragmentado en el espermatozoide puede tener un origen multifactorial, una de las líneas prioritarias de investigación se debiera centrar en llegar a comprender cuáles son lo mecanismos reales implicados en el disparo de este proceso y por otra, llegar a establecer con nitidez bajo qué circunstancias este factor afecta a la fertilidad de los individuos.

Por último, resaltar que no existe un consenso claro sobre la técnica que se debe utilizar para medir el daño en el DNA de los espermatozoides de pacientes considerados como sub-fértiles. Actualmente, dada su antigüedad, el SCSA es quizás la técnica que ha sido más empleada ${ }^{75}$. Sin embargo, es un método cuyo equipamiento limita su aplicación en un laboratorio básico de andrología. Otras alternativas como el SCD se muestran como de mayor proyección y fácil aplicación en la clínica rutinaria.

\section{Agradecimientos}

Los autores agradecen a la Coordinación de Investigación en Salud del IMSS, por el apoyo otorgado para la realización de estancias de investigación en el extranjero. Parte de este trabajo se realizó con los fondos de los proyectos PGIDIT05SAN43PR y BOS200304263 de la UAM.

\section{REFERENCIAS}

1. Spira A, Multigner L. Epidemiology of infertility in 1998 Sperm density and environment. En: M Filicori, C Flamigni (Eds.) Treatment of infertility: the new frontiers. Princeton Junction, New Jersey: Communication Media for Education, 1998.

2. World Health Organization. Laboratory manual for the examination of human semen and sperm-cervical mucus interaction. Ann Ist Super Sanita. 2001;37(1):I-XII, 1-123.

3. Guzick DS, Sullivan MW, Adamson GD, Cedars MI, Falk RJ, Peterson EP, et al. Efficacy of treatment for unexplained infertility. Fertil Steril. 1998;70(2):207-213.

4. Check JH, Graziano V, Cohen R, Krotec J, Check ML. Effect of an abnormal sperm chromatin structural assay (SCSA) on pregnancy outcome following (IVF) with ICSI in previous IVF failures. Arch Androl. 2005;51(2):121-124.

5. Aravindan GR, Bjordahl J, Jost LK, Evenson DP. Susceptibility of human sperm to in situ DNA denaturation is strongly correlated with DNA strand breaks identified by single-cell electrophoresis. Exp Cell Res. 1997;236(1):231237.
6. Zini A, Bielecki R, Phang D, Zenzes MT. Correlations between two markers of sperm DNA integrity, DNA denaturation and DNA fragmentation, in fertile and infertile men. Fertil Steril. 2001;75(4):674-677.

7. Tomlinson MJ, Moffatt O, Manicardi GC, Bizzaro D, Afnan M, Sakkas D. Interrelationships between seminal parameters and sperm nuclear DNA damage before and after density gradient centrifugation: implications for assisted conception. Hum Reprod. 2001;16(10):2160-2165.

8. Erenpreiss J, Hlevicka S, Zalkalns J, Erenpreisa J. Effect of leukocytospermia on sperm DNA integrity: a negative effect in abnormal semen samples. J Androl. 2002;23(5): 717-723.

9. Brinkworth MH. Paternal transmission of genetic damage: findings in animals and humans. Int $J$ Androl. 2000;23(3): 123-135.

10. Perreault SD. Distinguishing between fertilization failure and early pregnancy loss when identifying male-mediated adverse pregnancy outcomes. Adv Exp Med Biol. 2003; 518:189-198.

11. Aitken RJ, Krausz C. Oxidative stress, DNA damage and the Y chromosome. Reproduction. 2001;122(4):497-506.

12. Silber SJ, Repping S. Transmission of male infertility to future generations: lessons from the Y chromosome. Hum Reprod Update. 2002;8(3):217-229.

13. Ji BT, Shu XO, Linet MS, Zheng W, Wacholder S, Gao YT, et al. Paternal cigarette smoking and the risk of childhood cancer among offspring of nonsmoking mothers. $J$ Natl Cancer Inst. 1997;89(3):238-244.

14. Cox GF, Burger J, Lip V, Mau UA, Sperling K, Wu BL, et al. Intracytoplasmic sperm injection may increase the risk of imprinting defects. Am J Hum Genet. 2002;71(1):162-164.

15. Weber RF, Dohle GR, Romijn JC. Clinical laboratory evaluation of male subfertility. Adv Clin Chem. 2005;40:317-364.

16. Rubes J, Selevan SG, Evenson DP, Zudova D, Vozdova M, Zudova Z, et al. Episodic air pollution is associated with increased DNA fragmentation in human sperm without other changes in semen quality. Hum Reprod. 2005;20 (10):2776-2783.

17. Enciso M, Muriel L, Fernandez JL, Goyanes V, Segrelles E, Marcos M, et al. Infertile men with varicocele show a high relative proportion of sperm cells with intense nuclear damage level, evidenced by the sperm chromatin dispersion test. J Androl. 2006;27(1):106-111.

18. Lopes S, Sun JG, Jurisicova A, Meriano J, Casper RF. Sperm deoxyribonucleic acid fragmentation is increased in poor-quality semen samples and correlates with failed fertilization in intracytoplasmic sperm injection. Fertil Steril. 1998;69(3):528-532.

19. Gorczyca W, Gong J, Darzynkiewicz Z. Detection of DNA strand breaks in individual apoptotic cells by the in situ terminal deoxynucleotidyl transferase and nick translation assays. Cancer Res. 1993;53(8):1945-1951.

20. Manicardi GC, Bianchi PG, Pantano S, Azzoni P, Bizarro D, Bianchi U, et al. Presence of endogenous nicks in DNA of ejaculated human spermatozoa and its relationship to chromomycin A3 accessibility. Biol Reprod. 1995;52(4): 864-867.

21. Evenson DP, Darzynkiewicz Z, Melamed MR. Relation of mammalian sperm chromatin heterogeneity to fertility. Science. 1980;210(4474):1131-1133.

22. Fernandez JL, Vazquez-Gundin F, Delgado A, Goyanes VJ, Ramiro-Diaz J, de la Torre J, et al. DNA breakage detection-FISH (DBD-FISH) in Human spermatozoa: technical variants evidence different structural features. Mutat Res. 2000;453(1):77-82. 
23. Singh NP, McCoy MT, Tice RR, Schneider EL. A simple technique for quantitation of low levels of DNA damage in individual cells. Exp Cell Res. 1988;175(1):184-191.

24. Fernandez JL, Muriel L, Rivero MT, Goyanes V, Vazquez R, Alvarez JG. The sperm chromatin dispersion test: a simple method for the determination of sperm DNA fragmentation. J Androl. 2003;24(1):59-66.

25. Chohan KR, Griffin JT, Lafromboise M, De Jonge CJ, Carrell DT. Comparison of chromatin assays for DNA fragmentation evaluation in human sperm. $J$ Androl. 2006;27(1):53-59.

26. Ashok Agarwal \& Tamer M Said. In: Sperm chromatin assessment. Gardner DK. Textbook of assisted reproductive techniques: laboratory and clinical perspectives. Taylor\&Francis Ed. Philadelphia, USA. 2004.

27. Gorczyca W, Traganos F, Jesionowska H, Darzynkiewicz Z. Presence of DNA strand breaks and increased sensitivity of DNA in situ to denaturation in abnormal human sperm cells: analogy to apoptosis of somatic cells. Exp Cell Res. 1993;207(1):202-205.

28. Fernández JL, Goyanes V, Gosálvez J. DNA Breakage Detection-FISH (DBD-FISH). FISH Technology -Springer Lab Manual Editado por Dr. B. Rautenstrauss y Dr. Thomas Liehr. Springer-Verlag, Heidelberg. 2002.

29. Gwo JC, Wu CY, Chang WS, Cheng HY. Evaluation of damage in Pacific oyster (Crassostrea gigas) spermatozoa before and after cryopreservation using comet assay. Cryo Letters. 2003;24(3):171-180.

30. Fraser L. Structural damage to nuclear DNA in mammalian spermatozoa: its evaluation techniques and relationship with male infertility. Pol J Vet Sci. 2004;7(4):311-321.

31. Hoshi K, Katayose H, Yanagida K, Yimura Y, Sato A. The relationship between acridine orange fluorescence of sperm nuclei and the fertilizing ability of human sperm. Fertil Steril. 1996;66(4):634-639.

32. Evenson DP. Loss of livestock breeding efficiency due to uncompensable sperm nuclear defects. Reprod Fertil Dev. 1999;11(1):1-15.

33. Calvin H I, Bedford JM. Formation of disulfide bonds in the nucleus and accessory structures of mammalian spermatozoa during maturation in the epididymis. J Reprod. Fertil 1971;13 Suppl 13: 65-75.

34. Ward WS, Coffey DS. DNA packaging and organization in the mammalian spermatozoa: comparison with somatic cells. Biol Reprod. 1991;44(4):569-574.

35. Ward, WS. Deoxyribonucleic acid loop domain tertiary structure in mammalian spermatozoa. Biol Reprod. 1993;48(6): 1193-1201.

36. Fernandez JL, Muriel L, Goyanes V, Segrelles E, Gosalvez $J$, Enciso M, et al. Simple determination of human sperm DNA fragmentation with an improved sperm chromatin dispersion test. Fertil Steril. 2005;84(4):833-842.

37. Rodríguez S, Goyanes V, Segrelles E, Blasco M, Gosálvez J, Fernández JL. Critically short telomeres are associated with sperm DNA fragmentation. Fertil Steril. 2005; 84(4): 843-845.

38. Enciso M, López-Ferández C, Fernández JL, Garcia P, Gosálbez A, Gosálvez J. A new method to analyze boar sperm DNA fragmentation under bright-field or fluorescence microscopy. Theriogenology. 2006;65(2):308-316.

39. Tejada RI, Mitchell JC, Norman A, Marik JJ, Friedman S. A test for the practical evaluation of male fertility by acridine orange (AO) fluorescence. Fertil Steril. 1984;42(1):8791
40. Solis EA, Bouvet BR, Brufman AS, Feldman R, Gatti VN. The possible macrophage role in seminal fluid. Actas Urol Esp. 2003;27(3): 185-189.

41. Gopalkrishnan K, Hurkadli K, Padwal V, Balaiah D. Use of acridine orange to evaluate chromatin integrity of human spermatozoa in different groups of infertile men. Andrología. 1999;31(5):277-282.

42. Andreetta AM, Stockert JC, Barrera C. A simple method to detect sperm chromatin abnormalities: cytochemical mechanism and possible value in predicting semen quality in assisted reproductive procedures. Int J Androl. 1995; 18 Suppl 1:23-28.

43. Erenpreisa J, Erenpreiss J, Freivalds T, Slaidina M, Krampe R, Butikova J, et al. Toluidine blue test for sperm DNA integrity and elaboration of image cytometry algorithm. Cytometry A. 2003;52(1):19-27.

44. Nasr-Esfahani MH, Razavi S, Mardani M. Relation between different human sperm nuclear maturity tests and in vitro fertilization. J Assist Reprod Genet. 2001;18(4):219225.

45. Gandini L, Lombardo F, Paoli D, Caponecchia L, Familiari G, Verlengia C, et al. Study of apoptotic DNA fragmentation in human spermatozoa. Hum Reprod. 2000;15(4):830-839.

46. Saleh RA, Agarwal A, Nelson DR, Nada EA, El-Tonsy MH, Alvarez JG, et al. Increased sperm nuclear DNA damage in normozoospermic infertile men: a prospective study. Fertil Steril. 2002;78(2):313-318.

47. Sergerie M, Laforest G, Bujan L, Bissonnette F, Bleau G. Sperm DNA fragmentation: threshold value in male fertility. Hum Reprod. 2005;20(12):3446-3451.

48. Spano M, Bonde JP, Hjollund HI, Kolstad HA, Cordelli E, Leter G. Sperm chromatin damage impairs human fertility. The Danish First Pregnancy Planner Study Team. Fertil Steril. 2000;73(1):43-50.

49. Agarwal A, Allamaneni SS. The effect of sperm DNA damage on assisted reproduction outcomes. A review. Minerva Ginecol. 2004;56(3):235-245.

50. Giwercman A, Richthoff J, Hjollund H, Bonde JP, Jepson K, Frohm B, et al. Correlation between sperm motility and sperm chromatin structure assay parameters. Fertil Steril 2003;80(6): 1404-1412.

51. Peris SI, Morrier A, Dufour M, Bailey JL. Cryopreservation of ram semen facilitates sperm DNA damage: relationship between sperm andrological parameters and the sperm chromatin structure assay. J Androl. 2004;25(2):224-233.

52. Irvine DS, Twigg JP, Gordon EL, Fulton N, Milne PA, Aitken RJ. DNA integrity in human spermatozoa: relationships with semen quality. J Androl. 2000;21(1):33-44.

53. Payne JF, Raburn DJ, Couchman GM, Price TM, Jamison MG, Walmer DK. Redefining the relationship between sperm deoxyribonucleic acid fragmentation as measured by the sperm chromatin structure assay and outcomes of assisted reproductive techniques. Fertil Steril. 2005;84: 356-364.

54. Twigg J, Fulton N, Gomez E, Irvine DS, Aitken RJ. Analysis of the impact of intracellular reactive oxygen species generation on the structural and functional integrity of human spermatozoa: lipid peroxidation, DNA fragmentation and effectiveness of antioxidants. Hum Reprod. 1998;13(6): 1864-1871.

55. Ollero M, Gil-Guzmán E, López MC, Sharma RK, Agarwal A, Larson K, et al. Characterization of subsets of human spermatozoa at different stages of maturation: implications in the diagnosis and treatment of male infertility. Hum Reprod. 2001;16(9):1912-1921. 
56. Donnelli ET, Steele EK, McClure N, Lewis SE. Assessment of DNA integrity and morphology of ejaculated spermatozoa from fertile and infertile men before and after cryopreservation. Hum Reprod 2001;16(6):1191-1199.

57. Shen S, Khabani A, Klein N, Battaglia D. Statistical analysis of factors affecting fertilization rates and clinical outcome associated with intracytoplasmic sperm injection. Fertil Steril 2003;79(2):355-360.

58. Hammadeh ME, Stieber M, Haidl G, Schmidt W. Association between sperm cell chromatin condensation, morphology based on strict criteria, and fertilization, cleavage and pregnancy rates in an IVF program. Andrologia 1998;30(1):29-35.

59. Host E, Lindenberg S, Smidt-Jensen S. The role of DNA strand breaks in human spermatozoa used for IVF and ICSI. Acta Obstet Gynecol Scand 2000;79(7):559-563.

60. Larson-Cook KL, Brannian JD, Hansen KA, Kasperson KM, Aamold ET, Evenson DP. Relationship between the outcomes of assisted reproductive techniques and sperm DNA fragmentation as measured by the sperm chromatin structure assay. Fertil Steril 2003;80(4):895-902.

61. Duran EH, Morshedi M, Taylor S, Oehninger S. Sperm DNA quality predicts intrauterine insemination outcome: a prospective cohort study. Hum Reprod 2002;17(12): 31223128.

62. Saleh RA, Agarwal A, Nada ES, El-Tonsy MH, Sharma RK, Meyer A, et al. Negative effects of increased sperm DNA damage in relation to seminal oxidative stress in men with idiopathic and male factor infertility. Fertil Steril 2003;79 Suppl 3:1597-1605.

63. Bungum M, Humaidan P, Spano M, Jepson K, Bungum L, Giwercman A. TThe predictive value of sperm chromatin structure assay (SCSA) parameters for the outcome of intrauterine insemination, IVF and ICSI. Hum Reprod 2004;19(6):1401-1408.

64. Seli E, Gardner DK, Schoolcraft WB, Moffatt O, Sakkas D. Extent of nuclear DNA damage in ejaculated spermatozoa impacts on blastocyst development after in vitro fertilization. Fertil Steril 2004;82(2):378-383.

65. Tomsu M, Sharma V, Miller D. Embryo quality and IVF treatment outcomes may correlate with different sperm comet assay parameters. Hum Reprod 2002;17(7):18561862.

66. Sun JG, Jurisicova A, Casper RF. Detection of deoxyribonucleic acid fragmentation in human sperm: correlation with fertilization in vitro. Biol Reprod 1997; 56(3):602607.
67. Muriel L, Meseguer M, Fernandez JL, Alvarez J, Remohi J, Pellicer A, et al. Value of the sperm chromatin dispersion test in predicting pregnancy outcome in intrauterine insemination: a blind prospective study. Hum Reprod 2006; 21(3):738-744.

68. Genesca A, Caballin MR, Miro R, Benet J, Germa JR, Egozcue J. Repair of human sperm chromosome aberrations in the hamster egg. Hum Genet 1992; 89(2):181-186.

69. Carrell DT, Liu L, Peterson CM, Jones KP, Hatasaka HH, Erickson L, et al. Sperm DNA fragmentation is increased in couples with unexplained recurrent pregnancy loss. Arch Androl 2003;49(1):49-55.

70. Virro MR, Larson-Cook KL, Evenson DP. Sperm chromatin structure assay (SCSA) parameters are related to fertilization, blastocyst development, and ongoing pregnancy in in vitro fertilization and intracytoplasmic sperm injection cycles. Fertil Steril 2004; 81(5):1289-1295.

71. Gandini L, Lombardo F, Paoli D, Caruso F, Eleuteri P, Leter G, et al. Full-term pregnancies achieved with ICSI despite high levels of sperm chromatin damage. Hum Reprod 2004;19(6):1409-1417. Epub 2004 Apr 29.

72. Kobayashi H, Larson K, Sharman R, Nelson DR, Evenson DP, Toma AJ, et al. DNA damage in patients with untreated cancer as measured by the sperm chromatin structure assayDNA damage in cancer patients before treatment as measured by the sperm chromatin structure assay. Fertil Steril 2001;75(3):469-475.

73. Satta A, Stivala A, Garozzo A, Morello A, Perdichizzi A, Vicari E, et al. Experimental Chlamydia trachomatis infection causes apoptosis in human sperm. Hum Reprod 2006;21(1):134-137.

74. Connelly DA, Chan PJ, Patton WC, King A. Human sperm deoxyribonucleic acid fragmentation by specific types of papillomavirus. Am J Obstet Gynecol 2001;184(6): 1068-1070.

75. Erenpreiss J, Spano M, Erenpreisa J, Bunqum M, Giwercman A. Sperm chromatin structure and male fertility: biological and clinical aspectsSperm chromatin structure and male fertility: biological and clinical aspect. Asian J Androl 2006;8(1):11-29.

Correspondencia autor: Prof. J. Gosálvez

Departamento de Biología. Unidad de Genética

Universidad Autónoma de Madrid (UAM) 20849-Madrid

E-mail autor: jaime.gosalvez@uam.es

Información artículo: Original - Infertilidad

Trabajo recibido: noviembre 2006

Trabajo aceptado: diciembre 2006 